\title{
Caretaking Behavior among Siblings in Children's Shelters
}

\author{
Comportamento de Cuidado entre Irmãos em Instituição de Abrigo
}

\author{
Lília Iêda Chaves Cavalcante*, Lígia Negrão Costa, \& Celina Maria Colino Magalhães \\ Federal University of Pará, Belém, Brazil
}

\begin{abstract}
This study analyzed 742 events involving caretaking behavior among sheltered children with or without siblings in the same institution. Statistical tests were used for intergroup evaluation in comparison to focal subjects. Children with siblings showed a greater number of those behaviors and they were primarily directed to non-sibling peers (roommates) or adults (caretakers). The study also revealed that the caretaking behavior was more frequent in the group of children with siblings in the institution whereas those without siblings showed a more affective contact and behaviors directed more to adults than to peers. It was concluded that the caretaking behavior is present among siblings, but it assumes particular shapes because of the complex social dynamics that characterize the research environment.

Keywords: Prosocial behavior, sheltered children, siblings.

Resumo

Este estudo analisou 742 eventos envolvendo comportamento de cuidado entre crianças abrigadas com e sem irmão na mesma instituição. Foram aplicados testes estatísticos para avaliação intergrupal na comparação entre os sujeitos focais. As crianças com irmão manifestaram a maior proporção desses comportamentos e foram dirigidos principalmente a parceiros não-Irmãos (companheiros de dormitório) ou adultos (cuidadores). O estudo revelou ainda que o comportamento Brincar de cuidar foi mais freqüente no grupo de crianças Com Irmão na instituição enquanto que entre os participantes Sem Irmão predominou Estabelecer contato afetuoso e comportamentos direcionados mais a adultos do que aos pares. Conclui-se que o comportamento de cuidado está presente entre irmãos, mas assume formas particulares em razão da complexa dinâmica social que caracteriza o ambiente pesquisado.

Palavras-chave: Comportamento pró-social, crianças abrigadas, irmãos.
\end{abstract}

Researches have showed that children develop according to the interactions they maintain. In this sense, the prosocial behavior has been investigated as an interaction pattern with a particular influence on the development for involving voluntary actions from which children seek to help or beneficiate another subject or social groups as Eisenberg and Musen (1989) explain. For these authors this specific shape of behavior is under the effect of some factors as: (a) the cultural group to which the child belongs; (b) the early socialization experiences, the cognitive processes, the personal variables linked to personality (sex, age, economic class origin, position in the family, and characteristics as assertiveness, sociability, and selfesteem); and (c) the social circumstances that mark its

\footnotetext{
"Address: Instituto de Ciências Sociais Aplicadas, Federal University of Pará, Av. Augusto Correa, 1, Campus Universitário Guamá, Belém, Brazil 66075-900. E-mail: liliaccavalcante@gmail.com, ligia.negrao5@gmail.com and celinaufpa@gmail.com

The present study is part of the Doctoral Thesis "Ecology of Care: Interactions among the Child, the Environment, the Adults and the Peers in Shelter Institutions" submitted by the first author in 2008 for the Programa de Pós Graduação em Teoria e Pesquisa do Comportamento, Universidade Federal do Pará.
}

existence. Therefore, the authors cited above understand that the experiences related to social and cultural context in which the child is inserted and the factors from the immediate environment are associated to the basis of the prosocial behavior in the childhood.

Studies have clearly demonstrated that the child is capable of expressing attitudes that denote care with their peers besides a true concern to their welfare when the dynamic involves dyads and groups of siblings. Examining the literature it is possible to identify a group of studies that suggest a common presence of the care behavior among phratries. Many of them show aspects of the prosocial behavior manifestation among siblings in different social and cultural contexts, emphasizing the particularities of this living together in the infantile daily life (Conger, Stocker, \& McGuire, 2009) and its importance in the developmental pathway (Brody, 1998; Carreño \& Avilla, 2002). Having greater or smaller emphasis these authors advocate that siblings have a decisive role in the child's early socialization. The social interaction among them stimulates the prosociability in formation by promoting interpersonal knowledge among children, propitiating the attachment relation formation, offering samples of social relationship for future expe- 
riences and favoring the learning through social exchanges supported by intense interactions.

There are evidences that the interactional dynamics experienced by the phratry also favors the construction of more horizontal relationship based on the mutual help, the capacity of learning and doing things together, for the opportunity to communicate and to make themselves understood by their peers. In summary, the objective and subjective conditions in which the children interact with their brothers and sisters are contextual elements that not only have influence on how the care behavior will be maintained but also on how they acquire a special meaning in the formation of this interaction pattern throughout the childhood.

For this matter, it should be considered that experiences lived by dyads, triads, and groups of siblings in the family context tend to be repeated in other social environments, including infantile institutions such as day-care centers, schools, and shelters.

Although the literature on this subject is full of studies that discuss the interactions between siblings in the family environment (McGuire \& Shanahan, 2010), including in Brazil where there have been identified infantile care practices by siblings and their role as subsidiary attachment figures (Baia-Silva, 2006; Ferreira \& Mettel, 1999; Nunes \& Aiello, 2008; Poletto, Wagner, \& Koller, 2004; Soares, Franco, \& Carvalho, 2009), other studies investigate the prosocial behavior expression in institutional environment as shelters for children in abandonment and mistreatment conditions.

Since the clinical and observational registers made by Freud and Dann (1951/1967), in studies with the so called "war orphans" it's attempted to demonstrate how vital for the human survival and development the legacy from the relationship children have with their similar can be, especially if this relationship involves linked peers (brother and sisters and friends) and with a long institutionalization history. In recent studies a similar line of reasoning was presented by Carvalho (2000), when performing studies in three institutions for children (two day-care centers and one orphanage) involving 30 children in observation sessions for about 24 months. The researcher selected and analyzed 720 episodes described as complementary interactions between pairs who mimic the adult parental protection behavior, associating it to actions as helping, comforting, entertaining, establishing affective contact and care-taking play. The results of the previous research strengthen the hypothesis that the benefits of prosocial experiences are possible and welcoming as the care manifestations between pairs (especially when linked) guarantee comfort and protection to the child before odd situations in the institutional daily life.

Studies published by Dontas, Maratoso, Fafoutis e Karangelis (1985), involving participants ageing from five to eight months and from nine to twelve months, in Greece, showed that in a group formed by same-aged children no meaningful difference was observed in the interactions between acquainted or strange partners, according to the cohabitation criteria. However, among the participants from different ages it was verified more cooperation and synchrony in the interaction maintained by familiar pairs. The authors concluded that among acquainted children such as siblings, the older ones tend to be in charge of the youngest care and protection, standing nearby and being responsive to their demands, even in the institutional environment where the contextual conditions many times acts in the sense of keeping them socially and effectively apart from each other.

Based on these and other studies about prosocial behavior among institutionalized children, it is noticed that contextual changes that involve values, beliefs and traditions that are particulars of a culture, seem to act in the sense of modeling the natural human willingness to cooperate with partners from the same ascendency as discussed by Coll, Marchesi and Palacios (2002/2004). Likewise, the social and natural willingness to take care and protect a partner with a common family reference are present even in institutionalized children who live in environmental conditions not always favorable to physical and affective proximity among siblings. This pattern of behavior tends to vary according to the conditions imposed by the shelter management, favoring or not the connection of siblings apart from their families.

In a study that discusses the implications of the quality in the relationship between brothers and sister kept in asylum and foster homes Linares, Li, Shrout, Brody and Pettit (2007) highlight the central role of these experiences on the adaptation process to these contexts and the impact on behaviors that are capable of keeping them together and in safety when facing shortcomings. In accordance to it Alexandre and Vieira (2004) when studying the attachment relationship among institutionalized children and the demonstration of affection and care between pairs, verified that the role performed by the older siblings have a specific meaning and potential implications for the social, affective and cognitive development of the younger ones. The studied subjects present themselves resilient to pressures experienced up to then probably because they could count on some protection factors as the maintenance of positive affective bonds with older sibling or the institutions' employees.

Similar to what discussed Linares et al. (2007) and authors as Herrick and Piccus (2005), it is understood that in situations which children express affection and zeal towards their sibling and other partners, this experience can be essential to preserving mental health and training important social skills. It is supposed that prosocial behavior may have an even greater survival value when the living together happens in adverse material and affective condition, constituting an interesting topic of investigation the interactions among siblings in sheltering condition and its assumed importance for the preservation of family bonds. The interest for the investigation of multiple forms of manifestations of the care behavior in 
this specific context demands, however, a close look on the conditions in which groups of siblings effectively live in these protection institutions for the so called childhood at risk (Instituto de Pesquisa Econômica Aplicada [IPEA], 2004; Rizzini \& Rizzini, 2004).

Since the promulgation of the Child and Adolescent Statute (Estatuto da Criança e do Adolescente [ECA], 1990), shelters and other provisory care institutions have attempted to apply some measures to strengthen and keep affective bonds between the child and its family valuing the joint sheltering of siblings (Silva, 2004). According to data published by the IPEA (2004), in 2003, $63.8 \%$ of researched shelters in Brazil declared to adopt measures for prioritizing the maintenance or reconstitution of groups of siblings, this share also representing the north region. However, in what concerns to the dissemination of practices to stimulate the preservation of family ties some studies show that for the siblings to be in the same shelter there is a condition of similarity between them specially regarding to sex and age.

In this direction, a study performed by Carreirão (2005) points to several difficulties for the sheltering of siblings that could be summarized in: (a) the institutional policies should be better established when having as common goals the promotion, preservation and control of this essential right of the children and the adolescent; (b) the fulfillment of the rights of groups of siblings and their families by the municipal social programs presents many difficulties and restrictions of all sorts. In a different study Serrano (2008) investigated the situation of 258 children sheltered in facilities from the city of Ribeirão Preto in the state of São Paulo. The author shows that $78 \%$ of the children placed in the 4 researched shelters, ranging from 0 to 6 years old had siblings. Nonetheless, the tie preservation between them was associated to some conditions: (a) had being sheltered together, (b) could go back to their families of origin together, (c) had visits from siblings in the shelter, (d) had spent the weekend with the family and other gathering situations, (e) had the opportunity to met periodically, for example at school even if being in different shelters.

Based on theoretical or empirical studies that emphasize the importance to investigate the quality of the relationship between siblings, taking into consideration specific characteristics of the environment where interactions and behaviors take place, this article presents the results of a research that identified particular traits of the care behavior manifestation among children with and without siblings in an institution in Belém's Metropolitan Region, through events involving several partners, with the same or different ages, more specifically in the phratry context.

\section{Method}

\section{Participants}

From consulting the file of 287 children sheltered in the institution where this research took place, it was noted that after 12 months 58 still remained in the same conditions. From this sample only 10 attended the researchers' criteria: aged from 2 to 4 years, both sexes, and sheltered for at least one month. Therefore, didn't participate in the research children: out of the age range; in the initial stages of adaptation to the institution's routine; and/or at course of being unbound and return to the family living in the next three months.

Among the 10 children selected four of them were identified to have at least one sibling in the same facility center, but not in the same dormitory. They composed the subgroup formed by focal subjects with sheltered siblings. From the 6 children left 4 were selected to form a sample as large as the previews one, composed exclusively by focal subjects without a sibling in the shelter. The selection of the last 4 children was done randomly, by raffle.

At the end two samples were organized with four participants each with similar profiles related to sex and age, distinguishing only by the time spent in the institution. As a result, the subgroup 1 was composed by: 3 male and 1 female participants, ranging from 23 to 39 months of age, (mean 31.2), with a mean time in the institution of 14.5 months. Among them, 2 children had 3 siblings, 1 had one sibling and the other had 2 siblings. The subgroup 2 was composed by 4 focal subjects with no sibling in the shelter, 3 boys and 1 girl, with an age range from 23 to 39 months (mean 29.2). The mean time in the shelter was 26 months.

\section{Environment}

The shelter chosen for this research was created in 1994, with the objective of receiving temporally children in a condition of social vulnerability. The institution receives children aged from 0 to 6 years, boys and girls, accompanied or not by their siblings. Due to management regulations of the institution (to attend children younger than 6 years old and keep dormitory by age range) groups composed by siblings with a great age difference have, probably, no chance to stay together.

The observation sessions were mostly performed in common use areas, such as the cafeteria, video room, shed, garden, and yard. This decision took into consideration the hypothesis that these places work as a special loci for siblings separated due to the accommodation criteria to meet, for presenting free access and an intense flow of people.

\section{Instruments and Materials}

It was used a form to register the data collected from files of children which entered the institution in the 12 months considered for the research. This instrument was elaborated based on a previous study on the psychosocial condition of children who live in shelters and similar insti-tutions, developed by Weber and Kossobudzki (1996).

Another instrument was a standardized record sheet used for documenting the content from the observation 
sessions of focal subjects and the care behavior towards adults and pairs. This instrument was elaborated by the authors based on some questions proposed by Altmann (1993) with the proposition of organizing the registration of the data extracted from episodes recorded on VHS tapes, indicating minute by minute what the focal subject does, with whom and how he/she does it.

\section{Procedure}

A Judicial Authorization and Approval of the Research Project from the Ethics Committee. The first step was to obtain the authorization from the Child and Youth Court (Vara da Infância e Juventude) so the research could be performed in the shelter. Next, the proposal was sent to appreciation to the Human Research Ethics Committee which approved it under the protocol $n^{\circ} 062 / 2004-\mathrm{CEP} /$ MMT, in 09/08/2004.

Habituation Period. This stage lasted approximately 30 days. The objective was to make children and adults comfortable in the presence of the researcher without major disturbances of the institution's routine and the habitual subjects' manifestations.

Filling the Forms for the Children's Categorization. The files were examined and the information registered in a specific form. For further analyses some information were prioritized such as: family composition, number of siblings within this period, as well as information on the presence of groups of siblings in the institution and their profile.

Accomplishing the Observation Sessions of Children defined as Focal Subjects. The technique for observing the interactions of the focal subjects was naturalist (Altmann, 1993), it means that it was observed spontaneous behaviors of the participants in authentic environment of interaction with adults (educators, employees, volunteers, and family) and other children (siblings or not).

Each subject was observed for five minutes during 60 sessions. The total time for each participant was 300 minutes, always in the same research environment.

Data Analyses. First of all, it was realized the systematization of data related to number of siblings in the origin family and in the shelter according to the files. The statistical analysis was made based on the frequency and percentage calculus, both simple and accumulated.

In relation to the analyses of behavioral events the first step was the classification starting from subcategories pre-defined by Carvalho (2000) and Lordelo and Carvalho (1989):

1. Helping: initiative for doing something, offering to do something for the other person, or yet look for somebody else's help for the sake of the partner at a risk or difficult situation. In addition there is the feeding, sleeping and hygiene care as well as the care for the other's appearance and safety.

2. Care-taking play: attitudes of taking care that are experienced in a playful context, leading the child to make gestures which represent behaviors of attention, support and help towards the partner, on the other hand, they simulate or assume imaginary roles of typical caretakers and receivers whether humans (mother/child; grandfather/grandson; medic/patient) or in relation to animals (owner/pet).

3. Entertaining: the attitude of calling the other's attention to participate in a playful, fun, and relaxed activity. This behavior is demonstrated through gestures, speech, physical contact, making noise, using objects with the intention to amuse the partner, as well as the gesture of inviting and/or leading the other person in a walking situation or any other leisure activity.

4. Establishing affective contact: different forms of maintaining affective physical contact with the other people whereby attitudes as hugging, kissing and caressing can be identified.

For the data analysis it was necessary the frequency calculation of events related to each subcategory of the care behavior. In order to guarantee this study is biasfree all the data were analyzed a second time by and external investigator, with $80 \%$ of concordance.

Next, it was performed the statistical analysis evaluating the care behavior in the focal subjects sample. It was considered as subcategories helping, care-taking play, establishing affective contact, and entertaining, and as care targets siblings, non-siblings, adults and toys. A descriptive and inferential method was used, the Binomial Test for group assessment, for it enables to assess the difference between two sample proportions so it is possible to demonstrate which behaviors predominate in each group.

\section{Results and Discussion}

\section{Number of Siblings in the Family and in the Shelter}

The characterization of a population composed by 287 children in a sheltering situation showed that $68.88 \%$ had siblings in the origin family, from which most had 2 $(20.21 \%)$. Only a small parcel of the children had no siblings $(5.24 \%)$, it was a serious matter the number of the files which didn't contain any information about it $(25.88 \%)$. In contrast, almost a half of the children lived in the same institution with one $(26.14 \%)$, two $(15.68 \%)$ or three $(4.84 \%)$ siblings.

The results obtained from these data collection indicate that the sheltering of group of siblings is still a current and recurrent phenomenon. In Brazil, according to IPEA (2004), most children in shelters have familiar references $(87 \%)$, and have a history of living with the parents and/ or other relatives (siblings, grandparents, uncles and aunts), even if only a parcel keep contact with them by constant or sporadically visits $(58.2 \%)$

One other evidence that this is a present phenomenon relates to the fact that shelters adopt some measures for avoiding or restraining the dismemberment of groups of siblings. Among the most common are initiatives for prioritizing the siblings' mutual sheltering and promoting the 
Cavalcante, L. I. C., Costa, L. N. \& Magalhães, C. M. C. (2012). Caretaking Behavior among Siblings in Children's Shelters.

reunion of separate groups $(63.8 \%)$, organizing under vertical grouping assuring an age interval for being attended between minimum and maximum ten years $(62.1 \%)$ and coeducation system $(62.3 \%)$ according to Silva (2004). Considering the data from the north region it is observed that only $56 \%$ of shelters establish this range in 10 years, yet this characteristic favors receiving groups of siblings. This is the case of the shelter where this research took place, despite the fact that it assists boys and girls it focuses their assistance to children ranging from 0 to 6 years old, which excludes the possibility of receiving children with older sibling.

Another result obtained by this study concerns to the fact that children with higher number of siblings in the shelter are those which have the smallest number at home. This can mean that children from smaller families are being sent to shelters more often than those with larger number of siblings. This contradiction was also noted by Serrano (2008), with a possible explanation on the fact that in poor and numerous families it is common the figure of a child that takes care of the siblings in the absence of the parents or in cooperation to them (Baia-
Silva, 2006; Brody, 1998; Conger et al., 2009; Ferreira \& Mettel, 1999; Poletto et al., 2004).

\section{Care Behavior between Children With and Without Siblings}

According to the results derived from the focal subjects' observation it was found that, among the 8 subjects, all of them manifested behaviors of attention and zeal in the context considered for the research. In total 742 behavioral events were registered and organized according to these categories: establishing affective contact (53.78\%), helping $(36.52 \%)$, care-taking play $(9.3 \%)$ and entertaining (.04\%).

When describing the frequency in which these behaviors occurred in groups of focal subjects with siblings $(n=422)$ and without sibling $(n=320)$ in the shelter, it was found that with the exception of the subcategory establishing affective contact, all categories present a higher percentage in the first group in comparison to the second. However, from an intergroup assessment it was possible to realize that not always the difference in the observed proportion can be considered statistically significant as showed in Table 1.

Table 1

Events by Subcategories of the Care Behavior according to the Sample of Focal Subjects With and Without Sibling

\begin{tabular}{lccc}
$\begin{array}{l}\text { Subcategories } \\
\text { of the care behavior }\end{array}$ & $\begin{array}{c}\text { Group 1: } \\
\text { Focal SubjectsWith } \\
\text { sibling in the shelter } \\
n=422(\%)\end{array}$ & $\begin{array}{c}\text { Group 2: } \\
\text { Focal SubjectsWithout } \\
\text { sibling in the shelter } \\
n=320(\%)\end{array}$ & $p^{*}$ \\
\hline Helping & $162(38.39)$ & $109(34.06)$ & .2255 \\
Care-taking play & $64(15.17)$ & $5(1.56)$ & $<.0001$ \\
Establishing affective contact & $194(45.97)$ & $205(64.06)$ & $<.0001$ \\
Entertaining & $2(0.47)$ & $1(0.31)$ & .7315
\end{tabular}

$* p<.05$

The helping behavior shows in the group with sibling $(n=162 ; 38.39 \%)$ higher frequencies than the group without sibling ( $n=109 ; 34.06 \%)$, though this difference is not statistically significant $(p>.05)$. Therefore, the helping behavior is similar in both groups. The care-taking play behavior is most common in children with sibling $(p<.05)$. In relation to the behavior of entertaining, the difference obtained in the comparison between the samples is not important from the statistical point of view. In contrast, the behavior of establishing affective contact appears with significantly distant proportion $(p<.05)$ in the without sibling $(n=205 ; 64.06 \%)$ and with sibling groups ( $n=194 ; 45.97 \%$ ).

When it was investigated the focal subjects' target of care, it was observed that such behaviors are directed in a different way towards children, adults, and toys. Proceeding to a group assessment it is observed that when the receiver of the behavior is the child no-sibling, the caring behavior is similar in both groups (with sibling, $n=117,27.73 \%$; without sibling, $n=108,33.75 \%$ ). Nevertheless, when the receiver is part of the adult category the proportion of the care behavior is significantly larger in the group without sibling $(n=207,64.69 \%)$ in comparison to the one with sibling ( $n=186,44.08 \%)$. Comparatively, it is possible to affirm that caring behavior towards adults is more frequent among children who don't have brothers or sisters $(p<.01)$. On its turn, when this behavior is towards a toy it is significantly larger in the with sibling $(n=48,11.37 \%)$ group than in the without sibling one $(n=5,1.56 \%)$. As a result the caring behavior involving toys was more common among children with siblings.

In the shelter for children and in other collective care environment it is known that the intense living together socially approximates children and adults. This characte- 
ristic creates favorable conditions for the expression of affection from children to adults who take care of them more constantly and to the definition of the clear preference for same aged partners with whom they share the daily activities. The results corroborate the hypothesis that this type of living contributes to the formation of relationships marked by intimate and affective contact among the child and its caretaker and pairs, acting as a protection factor to the infantile development (Carvalho, 2000). On the other hand, the discrete presence of behavioral events involving only siblings can suggest, among other speculations, that the family bonds are in a fading process, which rises the debate about the possible effects of its dissolution for the developmental pathways with implications, especially after the sheltering period, as investigated Linares et al. (2007). According to them the risk of this experience can produce different impact on the children's behavior, mainly when they count with a shorter time with their siblings in the institution and/or due to a sudden interruption of their living together.
Results show yet that the helping behavior was observed more frequently in events that the receiver is from the same age, probably with similar physical aspects and intellectual maturation. These evidences indicate that it must be easier for the child to help, serve as a corporal support and cooperate with its equal than with an adult besides associating adults with people who give support, not the opposite. The same pattern is not seen in the establishing affective contact subcategory in which behaviors as hugging, kissing, or cherishing the adult many times work as a supplement in the search and maintenance of proximity with the caretaker. Such strategy can be decisive for the child's personal demands to be attended according to Carreño and Avilla (2002).

In Table 2 the results show more clearly that the way the child occupies itself with its peers' physical and emotional welfare tends to vary according to the interlocutor's personal characteristics as discussed by Eisenberg and Musen (1989) in a study about the roots of prosocial behavior in the childhood.

Table 2

Events by Subcategories of the Care Behavior according to the Provider or Receiver Category

\begin{tabular}{llccc}
\hline \multirow{2}{*}{$\begin{array}{l}\text { Subcategories } \\
\text { of the care behavior }\end{array}$} & Receiver & \multicolumn{2}{c}{ Provider } & $*$ \\
& & With Sibling & Without Sibling & \\
& & $n(\%)$ & $n(\%)$ & \\
\hline Helping $(n=271)$ & & $n=162$ & $n=109$ & \\
& Sibling & $38(23.45)$ & $0(0)$ & na \\
& Non-sibling & $72(44.45)$ & $73(66.95)$ & .0003 \\
& Adult & $52(32.10)$ & $36(33.04)$ & .8728 \\
& Toy & $0(0)$ & $0(0)$ & na \\
Care-taking play $(n=69)$ & & $n=64$ & $n=5$ & \\
& Sibling & $1(1.55)$ & $0(0)$ & na \\
& Non-sibling & $8(12.50)$ & $0(0)$ & na \\
& Adult & $11(17.19)$ & $0(0)$ & na \\
& Toy & $44(68.74)$ & $5(100)$ & .1380 \\
Entertaining $(n=3)$ & & $n=2$ & $n=1$ & \\
& Sibling & $0(0)$ & $0(0)$ & na \\
& Non-sibling & $2(100)$ & $1(100)$ & .9998 \\
& Adult & $0(0)$ & $0(0)$ & na \\
& Toy & $0(0)$ & $0(0)$ & na \\
Establishing affective contact $(n=399)$ & & $n=194$ & $n=205$ & \\
& Sibling & $32(16.49)$ & $0(0)$ & na \\
& Non-sibling & $35(18.04)$ & $34(16.58)$ & .7007 \\
& Adult & $123(63.41)$ & $171(83.42)$ & $<.0001$ \\
& Toy & $4(2.06)$ & $0(0)$ & na \\
\hline
\end{tabular}

Note. na: not applicable.

$* p<.05$.

From what it is exposed, when considering the receivers (sibling, non-sibling, adult and toy) it is noted that in the comparison between the provider group (with or without sibling) in general, the difference in the occurrences of behaviors are statistically significant. For the helping behavior the most expressive proportions were from the without siblings group towards peers from non-sibling category $(p<.01)$. Regarding the care-taking play it was 
also noticed statistically significant differences in comparison according to the provider and receiver categories $(p<.05)$. When the receiver is an adult it is noticed that again the Establishing affective contact behavior differs statistically between the groups $(p<.01)$, with a greater presence in the without sibling group ( $n=171,83.42 \%)$ when compared to the with sibling group $(n=123$; $63.41 \%$ ). However, in the same conditions, when the receiver is a non-sibling there was no difference in the statistical analysis.

Similar to what the literature shows it is seen that children when observed in their interactions: (a) show willingness to help those close to them, friends and with whom they lived/or knew the longest as discuss Eisenberg and Musen (1989), (b) demonstrate that the relationship with linked peers, as can be called siblings in a familiar context - but also the dormitory peers in an institutional environment - tend to be marked by affective contact as investigated by Brody (1998), Carreño and Avilla (2002), and McHale, Crouter and Whiteman (2003). Nonetheless, when this specific form of prosocial behavior involved exclusively siblings $(n=71)$, as care provider and receiver, the frequencies present smaller percentage than those obtained from the other peers' categories (habitual caretakers, and dormitory peers), as showed in Table 2. In an intergroup evaluation this type of event had the following results: helping $(n=38,23.45 \%)$, Establishing affective contact $(n=32,16.49 \%)$ and care-taking play $(n=1$, $1.55 \%)$.

These results are especially interesting when considering that whichever the considered contexts the identification of cooperation, comforting, and emotional support between peers have been associated to the construction of relationship with a certain level of stability, mutuality, and warmth, as explained by Bronfenbrenner (1979/ 1996). In addition, these behaviors can possibly relieve the anguish from specific situations where the adult may be unavailable for continuous interactions and the establishment of affective trades, a common characteristic which involve the social environment of institutions as orphanages and shelters (Carvalho, 2000).

By considering the hypothesis that prosocial behavior conceal additional benefits to the child institutionalized for a long period of time, it is noted that, investigation as this one present evidences on how this interaction pattern between siblings may also favor strategies for the preservation and strengthening of family ties.

Form an ecological perspective this kind of prosocial behavior can work as a protective factor for the development of children which are in sheltering institutions with a collective care, beneficiating specially dyads and groups of siblings. Allowing the reconstructions of intimate and lasting relationships that in general mark the relational context of phratry (Conger et al., 2009), the child can relive or keep the intimacy and affective atmosphere which surrounds these form of living, acting as an element with a clear importance in the ecology of the care dispensed to the sheltered child and for the preservation strategies of family ties during the stay in the institution.

\section{Final Considerations}

The psychosocial condition of the institutionalized child is considered as an object of interest for researchers, in classical experiments as well as contemporary studies. Recent studies emphasize that other factor than the chil-dren's age and time of their staying in the institution need to be assessed so it would be possible to predict, prevent or repair possible damages in the infantile development.

Thus, it is increasing the interest on studies about the quality of the interactions and relationships in the physical and social environment of the institution and its assumed influence on the children's early and life-long development. Apart from some few initiatives in this decade, it is still rare studies that specifically approach the universe of children's interaction and its effects on the institutionalized children social behavior, mostly when in early ages are put away from their parents and kept in shelters with their siblings for a prolonged time.

Through the literature analysis it appears that the mutual interaction of the child and the institutional environment is fundamental to find material, emotional and social encouragement compatible to their needs. The conditions favored by the social environment give the possibility for the child to build and/or maintain reference figures in the institution, including siblings, inasmuch as meaningful dyads as this one are present in other ecological environments besides the family one (Bronfenbrenner, 1979/ 1996).

The complexity of the caring behavior between siblings has a diversity of possible meanings capable of bringing out distinct motivation or impulses, however mutually beneficial. The child can be responsible for taking care of the sibling and in another moment became the target of behaviors expressing care, zeal and even attachment.

This study aimed at identifying particular forms of the manifestation of caring behavior in children with and without sibling in a shelter institution in Belém's metropolitan region, seeking to point differences in the proportion of events as helping, care-taking play, understanding and establishing affective contact, according to the provider and receiver categories.

When it was investigated the proportion of behaviors by focal subject groups with and without a sibling in the shelter it was noted that the events present significant variation in two out of the four categories. The care-taking play was more present among children with siblings; in contrast, the establishing affective contact was predominant in the group without sibling in the shelter. However, behaviors as helping and entertaining didn't 
have a significant variation in relation to the sample groups considered for this research, whereas behaviors representing affection demonstration (hugging, kissing, and caressing) are predominant among children with and without siblings in the same institution.

Results here presented indicate that the memory of prosocial interactions lived in family and the social meaning of this bond in this context tend to bring closer the siblings and keep them zealous with each other, even in a situation of prolonged institutionalization. Nonetheless, the content and quality of the relationship are sensible to the contextual conditions in which the siblings live and depend on the opportunities given to the rise of prosociability as an aspect of protection for the development.

In the researched context other results assume shapes of particular concerns: the socio-demographic data show that more than a half of the children were sent to provisory care accompanied by one or more siblings. From the total 287 children $68.88 \%$ belonged to groups of siblings. However, this percentage can be even higher when considering that $25.88 \%$ of the files consulted didn't present any data of this matter, turning this into a problem with indefinite proportions, so to speak. Whether little is yet known about who and how many they are, and how the siblings lived in their families, what can be said about their living together in a shelter environment?

On their turn, the behavioral data indicate it is necessary to rethink measures that can not only guarantee the sheltering of siblings but also provide more adequate conditions for preserving the groups and the ties capable of keeping them together. The intention must be to amplify the conditions to guarantee, among other things: (a) shared/joint sheltering, (b) creation of special dormitory for groups of siblings, mainly in the period for adaptation to the institution, (c) daily living in the shelter and other places as school, and other services, (d) periodic visits of the sibling in the shelter and to the origin family for successive approximation, (e) a single legal process for returning to the origin family or to foster homes (Herrick \& Piccus, 2005; Serrano, 2008).

This article points to the direction of a construction of a new look over old and complex questions related to the children's development which are living in an institutional environment. Thus, another study is starting in the same institution with the perspective of investigating more thoroughly aspects concerning the relationship of siblings in this place. Based on the results presented here it is supposed that this condition has implications for the ecology of the care lived in the institution (as well as in the family, the siblings share with educators, technicians and volunteers the attention directed to the younger ones), but also for the triumph of the processes of returning to the origin family or to the construction of family relations in a foster home (as in shelters, the siblings can help in the living of this ecological transitions and favoring the adaptation to the new environment).

\section{References}

Alexandre, D. T., \& Vieira, M. L. (2004). Relação de apego entre crianças institucionalizadas que vivem em situação de abrigo. Psicologia em Estudo, 9(2), 207-217.

Altmann, J. (1993). Observational study of behavior sampling methods. Behaviour, 49, 227-267.

Baia-Silva, S. D. (2006). Diferenças de gênero na interação entre irmãos em uma comunidade ribeirinha amazônica. (Dissertação de Mestrado não-publicada). Universidade Federal do Pará, Belém, PA.

Brody, G. (1998). Sibling relationship quality: Its causes and consequences. Annual Review Psychology, 49, 1-24.

Bronfenbrenner, U. (1996). A ecologia do desenvolvimento humano: Experimentos naturais e planejados. Porto Alegre, RS: Artes Médicas. (Original work published 1979)

Carreirão, U. L. (2005). Irmãos em abrigos: Possibilidades e limites para o resgate do direito à convivência familiar e comunitária. (Dissertação de Mestrado não-publicada). Universidade Federal de Santa Catarina, Florianópolis, SC.

Carreño, C. M., \& Avilla, S. C. (2002). El vínculo de apego entre hermanos: un estúdio exploratório com niños colombianos de estrato bajo. Suma Psicológica, 9, 107-132.

Carvalho, A. M. (2000). Fatores contextuais na emergência do comportamento de cuidado entre crianças. Psicologia: Reflexão e Crítica, 13, 81-88.

Coll, C., Marchesi, A., \& Palacios, J. (2004). Desenvolvimento ecológico e Educação. Psicologia Evolutiva (D. V. Moraes, Trad.). Porto Alegre, RS: Artmed (Original work published 2002)

Conger, K. J., Stocker, C., \& McGuire, S. (2009). Sibling socialization: The effects of stress-ful life events and experiences. In L. Kramer \& K. J. Conger (Eds.), Siblings as agents of socialization. New Directions for Child and Adolescent development (pp. 45-60). San Francisco: JosseyBass.

Dontas, C., Maratoso, O., Fafoutis, M., \& Karangelis, A. J. M. (1985). Early social development in institucionally reared Greek infants: Attachment and peers interaction. Monographs of the Society for Research in Child Development, 50, 136-146.

Eisenberg, N., \& Musen, P. H. (1989). The roots of prosocial behavior in children. Cambridge, UK: Cambridge University Press.

Estatuto da Criança e do Adolescente, Diário Oficial da União, Brasília, DF. (1990, 16 jul.). Retrieved July 8, 2009, from http://www.planalto.gov.br/ccivil/LEIS/L8069.htm

Ferreira, E. A. P., \& Mettel, T. P. L. (1999). Interação entre irmãos em situação de cuidados formais. Psicologia: Reflexão e Crítica, 12, 133-146.

Freud, A., \& Dann, S. (1967). An experiment in group upbringing. In Y. Blackbill \& G. G. Thomson (Eds.), Behavior in infancy and early childhood (pp. 494-514). New York: Free Press. (Original work published 1951)

Herrick, M. A., \& Piccus, W. (2005). Sibling connections: The importance of nurturing sibling bonds in the foster care system. Children and Youth Services Rewiew, 27, 845861 .

Instituto de Pesquisa Econômica Aplicada. (2004). Levantamento nacional de abrigos para crianças e adolescentes da rede $S A C$. Retrieved July 02, 2005, from http:// www.ipea.gov.br/default.jsp 
Linares, L. O., Li, M., Shrout, P. E., Brody, G., \& Pettit, G. S. (2007). Placement shift, sibling relationship quality, and child outcomes in foster care: A controlled study. Journal of Family Psychology, 21, 736-743.

Lordelo, E. R., \& Carvalho, A. M. A. (1989). Comportamento de cuidado entre crianças: Uma revisão. Psicologia: Teoria e Pesquisa, 5, 1-19.

McGuire, S., \& Shanahan, L. (2010). Sibling experiences in diverse family contexts. Social Development Perspectives, 2, 72-79.

McHale, S. M., Crouter, A. C., \& Whiteman, S. D. (2003). The family contexts of gender development in childhood and adolescence. Social Development, 12, 125-148.

Nunes, C. C., \& Aiello, A. L. R. (2008). Interação entre irmãos: Deficiência mental, idade e apoio social da família. Psicologia: Reflexão e Crítica, 21, 42-50.

Poleto, M., Wagner, T. M., \& Koller, S. H. (2004). Resiliência e desenvolvimento infantil de crianças que cuidam de crianças: Uma visão em perspectiva. Psicologia: Teoria e Pesquisa, 20, 241-250.

Rizzini, I., \& Rizzini, I. (2004). A institucionalização de crianças no Brasil: Percurso histórico e desafios do presente. São Paulo, SP: Loyola.

Serrano, S. A. (2008). O abrigamento de crianças de zero a seis anos de idade em Ribeirão Preto: Caracterizando esse contexto. (Tese de Doutorado não-publicada). Universidade de São Paulo, Ribeirão Preto, SP.

Silva, E. A. (2004). O direito à convivência familiar e comunitária: Os abrigos para crianças e adolescentes no Brasil. Brasília, DF: Instituto de Pesquisa Econômica Aplicada.

Soares, M. P. G., Franco, A. L. S., \& Carvalho, A. M. A. (2009). Crianças que cuidam de irmãos com necessidades especiais. Psicologia: Teoria e Pesquisa, 25, 45-54.

Weber, L. N. D., \& Kossobudzki, L. H. M. (1996). Filhos da solidão: Institucionalização, abandono e adoção. Curitiba, PR: Governo do Estado do Paraná. 